\title{
Best practices for smoking cessation interventions in primary care
}

\author{
Andrew Mclvor MD MSc FRCPC ${ }^{1}$, John Kayser RN BScN² , Jean-Marc Assaad PhD ${ }^{2,3}$, Gerald Brosky MD CCFP4, \\ Penny Demarest RN(EC) BScN${ }^{5}$, Philippe Desmarais BPharm ${ }^{6}$, Christine Hampson $\mathrm{PhD}^{7}$, Milan Khara $\mathrm{MBChB}^{8}$, \\ Ratsamy Pathammavong BSc $\mathrm{MSc}^{9}$, Robert Weinberg MD ${ }^{10}$
}

A McIvor, J Kayser, J-M Assaad, et al. Best practices for smoking cessation interventions in primary care. Can Respir J 2009;16(4):129-134.

BACKGROUND: In Canada, smoking is the leading preventable cause of premature death. Family physicians and nurse practitioners are uniquely positioned to initiate smoking cessation. Because smoking is a chronic addiction, repeated, opportunity-based interventions are most effective in addressing physical dependence and modifying deeply ingrained patterns of beliefs and behaviour. However, only a small minority of family physicians provide thorough smoking cessation counselling and less than onehalf offer adjunct support to patients.

OBJECTIVE: To identify the key steps family physicians and nurse practitioners can take to strengthen effective smoking cessation interventions for their patients.

METHODS: A multidisciplinary panel of health care practitioners involved with smoking cessation from across Canada was convened to discuss best practices derived from international guidelines, including those from the United States, Europe, and Australia, and other relevant literature. The panellists subsequently refined their findings in the form of the present article.

RESULTS: The present paper outlines best practices for brief and effective counselling for, and treatment of, tobacco addiction. By adopting a simple series of questions, taking $30 \mathrm{~s}$ to $3 \mathrm{~min}$ to complete, health care professionals can initiate smoking cessation interventions. Integrating these strategies into daily practice provides opportunities to significantly improve the quality and duration of patients' lives.

CONCLUSION: Tobacco addiction is the most important preventable cause of morbidity and mortality in Canada. Family physicians, nurse practitioners and other front-line health care professionals are well positioned to influence and assist their patients in quitting, thereby reducing the burden on both personal health and the public health care system.

\section{Key Words: Behavioural intervention; Smoking cessation; Tobacco}

\section{Pratiques optimales en matière d'interventions antitabagiques en soins primaires}

HISTORIQUE : Au Canada, le tabagisme est la principale cause évitable de mortalité précoce. Les médecins de famille et les infirmières praticiennes occupent une position privilégiée pour encourager l'abandon du tabac. Étant donné que le tabagisme est une dépendance chronique, les interventions répétées à chaque occasion offerte sont les plus efficaces pour corriger la dépendance physique et modifier des comportements et des croyances profondément encrées. Toutefois, seule une petite minorité de médecins de famille offrent un counselling antitabagique complet et moins de la moitié offrent un soutien supplémentaire aux patients.

OBJECTIF : Identifier les principales étapes que peuvent suivre les médecins de famille et les infirmières praticiennes pour consolider et rendre plus efficaces leurs interventions antitabagiques auprès de leurs patients.

MÉTHODES : Un comité pluridisciplinaire de professionnels de la santé ayant un intérêt pour la lutte au tabagisme s'est réuni afin de discuter de ces pratiques optimales, en s'inspirant de diverses directives internationales, y compris celles des États-Unis, de l'Europe et de l'Australie, et d'autres énoncés pertinents. Les membres du comité, originaires des quatre coins du Canada, ont par la suite synthétisé leurs conclusions pour produire le présent article.

RÉSULTATS : Cet article résume les pratiques optimales pour un counselling antitabagique bref et efficace et pour son traitement. Une simple série de questions qui ne demandent pas plus de 30 secondes à trois minutes permet aux professionnels de la santé d'instaurer des interventions antitabagiques. L'intégration de ces stratégies à la pratique quotidienne procure des occasions d'améliorer significativement la qualité et la durée de vie des patients.

CONCLUSION : La dépendance au tabac est la plus importante cause évitable de morbidité et de mortalité au Canada. Les médecins de famille, les infirmières praticiennes et autres professionnels de la santé qui se trouvent sur la ligne de front occupent une position idéale pour influencer et aider leurs patients qui souhaitent cesser de fumer, ce qui allègera le fardeau de la maladie tant pour les individus que pour le système de santé public.

than women are current smokers, but this gap is closing because more men are quitting whereas quit rates among women have plateaued. Overall, smoking prevalence has decreased significantly in the past decade. This is likely due to an increase in tobacco prices, public education about the dangers of smoking, the existence of smoking bans in public places from coast to coast, changes in the public's and the media's attitudes toward smoking, and the availability of new and more efficacious treatments for tobacco dependence.

Busy practitioners sometimes miss the opportunity for providing smoking cessation interventions because of competing health priorities, lack of confidence and the significant (16.4\%) and Ontario (16.6\%) (Figure 1). More Canadian men

${ }^{1}$ Department of Medicine, McMaster University, Firestone Institute for Respiratory Health, St Joseph's Healthcare, Hamilton, Ontario; ${ }^{2}$ Montreal Chest Institute, McGill University Health Centre; ${ }^{3} \mathrm{McGill}$ University Health Centre, and PsyMontréal Inc, Montreal, Quebec; ${ }^{4}$ Department of Family Medicine, Dalhousie University, and Cowie Family Medicine, Halifax, Nova Scotia; ${ }^{5}$ Hunter Street Medical Centre, Woodstock, Ontario; ${ }^{6}$ Pharmacist, Montreal, Quebec; ${ }^{7}$ Asthma Society of Canada, Toronto, Ontario; ${ }^{8}$ Tobacco Dependence Clinic, Vancouver Coastal

Health, Vancouver, British Columbia; ${ }^{9}$ Ontario Lung Association; ${ }^{10}$ Etobicoke Medical Centre, Toronto, Ontario

Correspondence: Dr Andrew McIvor, McMaster University, St Joseph's Healthcare, Firestone Institute for Respiratory Health, T2127, 50 Charlton

Avenue East, Hamilton, Ontario L8N 4A6. Telephone 905-522-1155 ext 35872,fax 905-521-6183, e-mail amcivor@stjosham.on.ca 


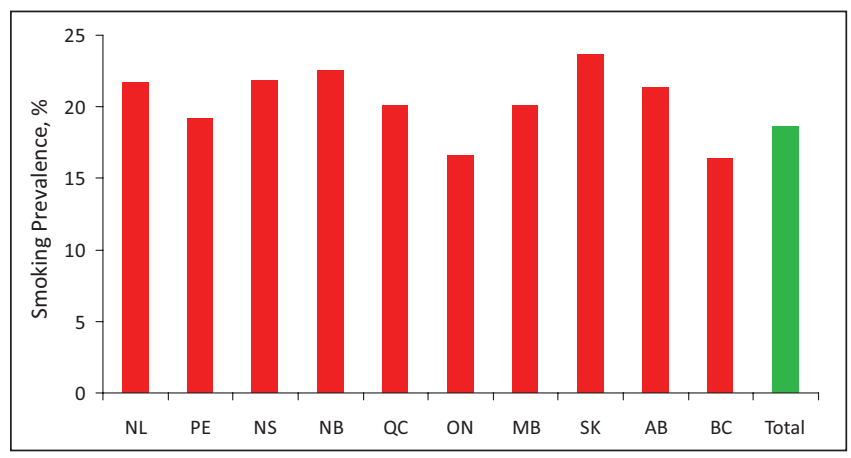

Figure 1) The percentage of current smokers by province, 2006. The column at the far right represents the national rate (Total). AB Alberta; BC British Columbia; MB Manitoba; NB New Brunswick; NL Newfoundland and Labrador; NS Nova Scotia; ON Ontario; PE Prince Edward Island; QC Quebec; SK Saskatchewan. Data adapted from the Canadian Tobacco Using Monitoring Survey 2006 (4)

difficulties patients have in quitting, even in the face of serious smoking-related illnesses (5). Moreover, certain myths persist that prevent some health care providers from following through with smoking cessation advice (Table 1). This helps explain why a survey (6) of family physicians in Montreal, Quebec, found that only $10.5 \%$ provided 'thorough' smoking cessation counselling, and less than one-half offered adjunct support to patients. In contrast, a recent survey (7) found that more than one-half of smokers would be interested in nicotine replacement therapy if it were offered free of charge.

Smoking kills one in two smokers (8), and the sequelae of tobacco dependence kill approximately $10 \%$ of adults worldwide (9). No other product exists that causes the premature death of $50 \%$ of those who use it exactly as intended. Tobacco use is a risk factor for six of the eight leading causes of death worldwide, including ischemic heart disease, cerebrovascular disease, lower respiratory infections, chronic obstructive pulmonary disease, tuberculosis, and cancers of the trachea, bronchus and lung (10). Moreover, recent data from the Nurses' Health Study (11) indicate that current smokers have nearly three times the risk of premature death compared with nonsmokers. The data also show that smokers have more than seven times the risk of developing smoking-related cancers. Another study (12) indicated that when heavy smokers reduced their daily cigarette smoking by as much as 50\% without going on to quit, their risk for premature death is not significantly lowered.

In Canada, smoking is the leading preventable cause of premature death (13). It is estimated that 515,608 years of life were lost prematurely in Canada in 2002 - 316,417 years in men and 199,191 years in women (14). Family physicians and nurse practitioners are uniquely positioned to initiate smoking cessation because they see their patients more frequently and for longer periods of time than do specialists, and often develop a strong rapport with their patients. Because smoking is a chronic addiction, repeated, opportunity-based interventions are most effective in addressing physical dependence and modifying deeply ingrained patterns of beliefs and behaviour. Simple counselling advice, support and appropriate pharmacotherapy
TABLE 1

\section{Common myths among physicians regarding smoking}

Myth 1 Smokers do not like to be asked about their smoking behaviour

Fact Patients have a positive view of health care providers who inquire about their smoking status; and believe the providers are not fulfilling their duty if they do not inquire

Myth 2 Reducing smoking but not stopping, lowers your risk of adverse outcomes

Fact The recent Lung Health Study from the United States (12) showed no reduction of myocardial infarction and other adverse outcomes in patients who significantly reduced but did not quit smoking. By contrast, quitting smoking entirely, at any age, significantly increases life expectancy (27)

Myth 3 Most smokers do not want to quit

Fact Approximately $60 \%$ of all smokers are at least thinking about, or are actually preparing to quit smoking (28)

Myth 4 A very brief discussion regarding smoking cessation is not effective

Fact A randomized, controlled trial has shown that motivational interviewing was 5.2 times more effective than simply providing brief antismoking advice (19)

can be effective in many cases $(1,2)$. The present article identifies current international best practices that family physicians and nurse practitioners can use to help their patients stop smoking and discusses them into the context of therapies available in Canada.

\section{METHODS}

To better understand effective best practices for family physicians, nurse practitioners and other health care professionals, an expert multidisciplinary panel was convened in March 2008 in Toronto, Ontario. The panel represented the fields of respirology, family practice, nursing, psychology (behaviour and addiction) and nongovernmental association representatives.

The panel reviewed published literature, clinical evidence and established international guidelines from the United States (1,2), Europe (15) and Australia (16), and discussed approaches from these sources proven to aid health care professionals in executing successful smoking cessation interventions. The best practices described in the present article are the result of these discussions.

The authors' intent was not to create new guidelines for smoking cessation, but instead to interpret existing guidelines for front-line clinicians in Canada. Our objective was to identify the key steps Canadian family physicians and nurse practitioners can take to strengthen effective smoking cessation interventions for their patients. Because the existing guidelines have thoroughly analyzed thousands of relevant studies, they serve as the primary source material for the present review but are supplemented by key recent studies that were suggested by the writing group to highlight key points in the guidelines and to underscore clinical best practices based on the authors' clinical experience.

\section{RESULTS}

Initiating smoking cessation behavioural interventions Encouraging smoking cessation has been recognized for many years as one of the most effective and least time-consuming methods in which physicians can improve personal and public health. Recent American (1,2), European (15) and Australian 


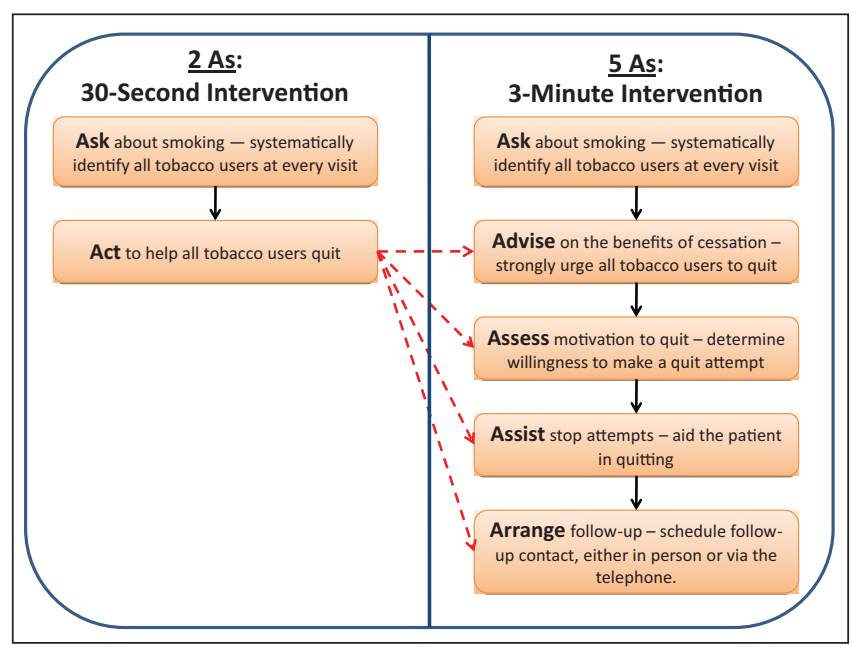

Figure 2) The '5 As' and ' 2 As' of smoking cessation. The '5 As' (right panel) are well known, commonly used in clinical practice and take at least $3 \mathrm{~min}$ to complete $(1,2)$. Recently, the American Academy of Family Physicians endorsed a two-step approach (the '2 As' - Ask and Act) to smoking cessation intervention (left panel) (17). It requires approximately $30 \mathrm{~s}$ to complete and involves asking patients about smoking behaviour and acting to help them quit. This is the minimum strategy that should be considered for every patient who currently smokes

(16) guidelines provide evidence-based recommendations on tobacco dependence. They summarize the more than 6000 English-language, peer-reviewed articles and abstracts regarding smoking assessment and treatment that have been published in the past 25 years $(1,2,15,16)$. The American guidelines are the most comprehensive; more than 50 meta-analyses were conducted as part of the process $(1,2)$.

These reviews demonstrate conclusively that the most successful smoking cessation efforts combine brief counselling, support and appropriate pharmacotherapy $(1,2)$. The American guidelines stress that tobacco use should be addressed at every patient visit using the '5 As' (Ask, Advise, Assess, Assist and Arrange) (1,2). The guidelines note that the 5 As can be covered in as little as $3 \mathrm{~min}$. Separately, the American Academy of Family Physicians summarizes the steps in a simpler and easier to use format called the ' 2 As' (ie, Ask and Act) (17). Figure 2 summarizes and compares the two approaches.

Evidence from two randomized controlled trials $(18,19)$ supports the greater effectiveness of motivational interviewing, compared with simply providing brief advice to quit smoking if time is available. Motivational interviewing is defined as a direct, patient-centred counselling intervention guided by four general principles that include expressing empathy, developing discrepancy (to help smokers appreciate the value of change by exploring the discrepancy between how they want their lives to be versus how they are curently), rolling with resistance and supporting self-efficacy (2). The American guidelines recommend the use of motivational interviewing for patients unwilling to quit smoking because this technique has been found to be effective in increasing future quit attempts (2). It is recommended that clinicians receive training in the use of this specialized technique (2). Further guidance on motivational interviewing is contained in the American guidelines (2).

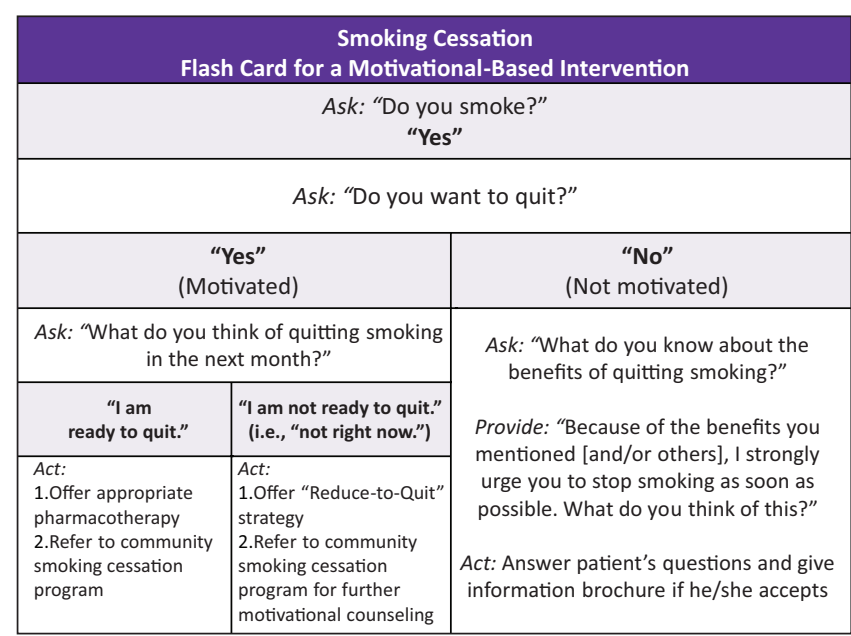

Figure 3) Brief algorithm for use as a flash card - a motivation-based intervention. This flash card can be copied and reduced to a pocketsized reference tool to aid in every encounter with a patient who smokes

To guide clinicians in using a motivational-based intervention most efficiently and effectively in the little time they have available, we have created an intervention algorithm as a flashcard for use during patient encounters (Figure 3). It can be used with all individuals regardless of whether they are prepared to quit smoking immediately.

According to the American guidelines, more intensive support is more effective and can be delivered by treatment specialists. Such support may include intensive counselling, culture-specific counselling, visits to more than one consulting physician, intratreatment social support, group counselling sessions and other areas of support that are beyond what a single clinician may be able to offer (2). In addition, the guidelines emphasize that unless contraindicated, pharmacological aids should be offered to every patient who smokes because these aids approximately double cessation rates (also referred to as 'quit rates') (1,2). When smokers are ready to quit and request help to do so, the best results occur from combining pharmacotherapy with a comprehensive behavioural change program. Thus, patients who would like to quit - or who have recently quit and could benefit from support in maintaining abstinence should be encouraged to visit a smoking cessation centre if one exists in their area or access a help line. These centres and helplines specialize in helping patients move toward change using state-of-the-art motivational and behavioural approaches.

Clinicians should also keep in mind that they can enhance quit rates by encouraging all of their patients to change to a healthy lifestyle, which includes regular exercise, eating more fruits and vegetables, and limiting alcohol consumption (20).

The key intervention is one in which physicians should ask all patients whether they smoke at each appropriate opportunity and, if they are current smokers, encourage them to quit. This simple intervention can double or triple quit rates (3), and is endorsed by the Canadian Cancer Society (21) and the Canadian Medical Association (22). Physicians should consider it their medical responsibility to intervene and offer treatment to their patients who smoke. The family physician visit 


\section{TABLE 2}

\section{Smoking cessation resources/Web sites for family physicians and patients}

Health Canada, www.hc-sc.gc.ca/english/tobacco.html or www.hc-sc.gc.ca/hl-vs/tobac-tabac/quit-cesser/index_e.html

National Clearinghouse on Tobacco and Health, www.ctc.ca/ncth

Smokers helpline, Web site www.smokershelpline.ca

Newfoundland/Labrador: 1-800-363-5864; Prince Edward Island: 1-888-818-6300; Nova Scotia, New Brunswick, Ontario, Manitoba and Saskatchewan:

1-877-513-5333; J'arrête Smokers' Helpline in Quebec: 1-866-527-7383; www.jarrete.qc.ca/; Quebec Lung Association: 1-888-768-6669 ext. 232;

Alberta: 1-866-332-2322; British Columbia: 1-877-455-2233

Canadian Council for Tobacco Control, www.cctc.ca

Conseil québécois sur le tabac et la santé: www.cqts.qc.ca/

Cancer Care Ontario, www.cancercare.on.ca/english/pcs/prevention/tobacco/. Frequently asked questions regarding smoking cessation, as well as a free service that sends motivational e-mails or voice mails to patients

For training physicians, nurse practitioners and pharmacists in smoking cessation

All Provinces: Call your local public health department

\section{British Columbia}

BC Lung Association, 2675 Oak Street, Vancouver, British Columbia V6H 2K2. Telephone 604-731-LUNG (5864) or toll free 1-800-665-LUNG (5864),

fax 604-731-5810, e-mail info@bc.lung.ca (The BC Lung Association offers professional training in smoking cessation)

\section{Ontario}

Clinical Tobacco Intervention (CTI) Program, Ontario Medical Association, 525 University Avenue, Suite 200, Toronto, Ontario M5G 2K7. Telephone 416-599-2580 ext 3229 or toll free 1-800-268-7215 ext 3229, fax 416-340-2238, e-mail cti@oma.org, Web site www.ctica.org/ (CTI provides an evidence-based approach and is a cooperative effort of the Ontario Medical Association, Ontario Pharmacists' Association and Ontario Dental Association)

The Training Enhancement in Applied Cessation Counselling and Health (TEACH) Project, 175 College Street, 3rd Floor, Toronto, Ontario M5T 1P7. Telephone 416-535-8501 ext 1600, fax 416-599-3802, e-mail teach@camh.net, Web site www.teachproject.ca (The TEACH project is geared toward training health care professionals in the public, private and nonprofit sectors who provide counselling services to people who use tobacco)

Registered Nurses' Association of Ontario (RNAO), 158 Pearl Street, Toronto, Ontario M5H 1L3, Telephone 416-599-1925 or toll free 1-800-268-7199, fax 416-599-1926, e-mail info@rnao.org, Web site www.rnao.org (The RNAO has created best practice guidelines for smoking cessation that are followed by many local boards of health in Ontario)

\section{Quebec}

Fédération des médecins omnipraticiens du Québec, 1440, rue Sainte-Catherine Ouest, bureau 1000, Montréal, Québec H3G 1R8, Téléphone 514-878-1911 Interurbain sans frais : 1-800-361-8499, Télécopieur : 514-878-4455, e-mail : info@fmoq.org (They published an intervention guideline 'Medical Support for Quitting Smoking')

In collaboration with the Quebec Lung Association, PsyMontréal Inc provides the 'Freedom From Smoking' training. PsyMontréal Inc, telephone/fax 514-337-2473 ext 1, e-mail formation@psymontreal.com, Web site www.PsyMontreal.com

This list may not be exhaustive. For training physicians and nurse practitioners in motivational interviewing, worldwide trainings in several languages are given by the Motivational Interviewing Network of Trainers <www.motivationalinterview.org/>

for smoking-cessation treatment is covered by provincial health insurance in every province except Alberta. Moreover, family physicians can act in concert with nurses, pharmacists and other members of the health care team to ensure that every strategy relating to smoking cessation is used effectively. A list of smoking cessation resources is provided in Table 2 .

\section{Pharmacotherapy}

Clinicians should offer to prescribe pharmacotherapy to anyone attempting to quit smoking, except to those with contraindications such as certain medical conditions or pregnancy. Therapies that have been shown to be effective for smoking cessation and are recommended as first-line treatment in Canada include the following (Table 3) (20):

For smokers motivated to quit smoking:

- Nicotine replacement therapy:

- Nicotine patch;

- Nicotine gum;

- Nicotine inhaler; or

- Nicotine sublingual lozenge

- Sustained-release bupropion hydrochloride

- Varenicline

A recent Canadian meta-analysis of 69 placebo-controlled randomized clinical trials (23) concluded that nicotine replacement therapy, bupropion and varenicline were all more efficacious than placebo in promoting smoking cessation.

Nicotine gum is recommended for smokers motivated to reduce the amount they smoke.

The 'Reduce to Quit' program (24) tailors nicotine-gum use and gradual reduction in the number of cigarettes smoked per day to the individual smoker's habits, aiming at smoking cessation in eight to 12 weeks.

\section{Additional pharmacotherapy}

The combination of bupropion and nicotine replacement can be considered if bupropion alone is ineffective $(1,15,20)$. Long-term treatment with all forms of pharmacotherapy are gaining increasing acceptance in clinical tobacco dependency treatment, and various combinations of treatments - particularly those involving nicotine replacement therapy - are earning a place in relapse prevention (1,2). Relapse is defined in the American guidelines as "a return to regular smoking by someone who has quit" (2).

The 2008 American guidelines point to the need to titrate nicotine replacement therapy in some patients using combinations of therapy such as a daily nicotine patch plus the use of an inhaler as needed, gum or lozenge, or the use of two patches in patients smoking more than one pack of cigarettes per day $(1,2)$. Many statements from patients such as “the patch doesn't work 
TABLE 3

Pharmacological aids for smoking cessation currently available in Canada

\begin{tabular}{|c|c|c|c|c|}
\hline Therapy/drug & Dose & Duration of treatment & Contraindications & Adverse effects* \\
\hline $\begin{array}{l}\text { Nicotine replacement } \\
\text { therapy }\end{array}$ & $\begin{array}{l}\text { Dose is adjusted to level of } \\
\text { nicotine dependence and is } \\
\text { decreased progressively over } \\
\text { the treatment period } \\
\text { Patch: } 21 \mathrm{mg} / \text { day to } 42 \mathrm{mg} / \text { day } \\
\text { initially } \\
\text { Gum: } 8 \text { to } 10 \text { pieces } \\
\text { ( } 2 \text { mg or } 4 \text { mg each)/day } \\
\text { Inhaler: } 4 \text { to } 6 \text { puffs/day } \\
\text { Lozenges: } 9 \text { to } 20 \text { lozenges/day }\end{array}$ & $\begin{array}{l}8 \text { to } 12 \text { weeks, can be longer } \\
\text { (up to } 1 \text { year) for the } \\
\text { prevention of relapse }\end{array}$ & $\begin{array}{l}\text { Patch: allergy to constituent of } \\
\text { nicotine patch }\end{array}$ & $\begin{array}{l}\text { Patch: Skin irritation, sleep } \\
\text { disturbance } \\
\text { Gum or lozenge: Mouth irritation, } \\
\text { sore jaw, dyspepsia, hiccups } \\
\text { Inhaler: Mouth and throat } \\
\text { irritation, cough }\end{array}$ \\
\hline $\begin{array}{l}\text { Nicotine gum - } \\
\text { 'Reduce-to-Quit' } \\
\text { program }\end{array}$ & $\begin{array}{l}\text { Rate of reduction of number of } \\
\text { cigarettes smoked/day and } \\
\text { replacement with gum tailored to } \\
\text { the individual smoker's smoking } \\
\text { habits }\end{array}$ & 8 to 12 weeks & None & $\begin{array}{l}\text { Abnormal dreams, diarrhea, } \\
\text { poor sleep, dry mouth, joint } \\
\text { pain, muscle pain, nervous- } \\
\text { ness, redness, itching or } \\
\text { burning at the application site; } \\
\text { sweating, weakness }\end{array}$ \\
\hline $\begin{array}{l}\text { Bupropion } \\
\text { hydrochloride, } \\
\text { sustained release }\end{array}$ & $\begin{array}{l}150 \mathrm{mg} / \text { day for first } 3 \text { days, } \\
\text { then } 300 \mathrm{mg} / \text { day }\end{array}$ & $\begin{array}{l}8 \text { weeks; can be longer } \\
\text { (up to } 1 \text { year) for the } \\
\text { prevention of relapse }\end{array}$ & $\begin{array}{l}\text { Seizure, central nervous system } \\
\text { tumour, bipolar disorder, alcohol } \\
\text { withdrawal, benzodiazepine } \\
\text { withdrawal, use of monoamine } \\
\text { oxidase inhibitor, anorexia, } \\
\text { bulimia and liver disease }\end{array}$ & $\begin{array}{l}\text { Insomnia, seizure, } \\
\text { gastrointestinal disturbance, } \\
\text { jitteriness }\end{array}$ \\
\hline Varenicline & $\begin{array}{l}0.5 \mathrm{mg} / \text { day for first } 3 \text { days, then } \\
0.5 \mathrm{mg} \text { twice daily for the next } \\
4 \text { days and } 1 \mathrm{mg} \text { twice daily } \\
\text { thereafter }\end{array}$ & $\begin{array}{l}12 \text { weeks; can be longer } \\
\text { (up to } 24 \text { weeks) for the } \\
\text { prevention of relapse }\end{array}$ & None & $\begin{array}{l}\text { Nausea, vomiting, constipation, } \\
\text { flatulence, bad taste in the } \\
\text { mouth, abnormal dreams, } \\
\text { sleep disturbance, depressed } \\
\text { mood, agitation, changes in } \\
\text { behaviour, suicidal ideation } \\
\text { and suicide }\end{array}$ \\
\hline
\end{tabular}

${ }^{*}$ Most frequent adverse events. Data adapted from reference 20 and supplemented by data from reference 25

at all", reflect the fact that their personalized nicotine needs are not being met, rather than a lack of efficacy of the treatments.

Recommended follow-up during pharmacotherapy treatment Because of the potential side effects from all medications, the sometimes severe withdrawal symptoms experienced by recent ex-smokers, and the high risk of early relapse, patients should be seen again by the physician or a nurse practitioner within approximately two weeks after the patient's quit date (ie, the date scheduled for the start of their smoking cessation) for brief relapse-prevention treatment or be instructed to contact the office if they are having difficulties (20). This follow-up has been particularly emphasized in warnings issued by Health Canada regarding the use of varenicline in patients with a neuropsychiatric history (25), but it is prudent in all treatment regimens to ensure adequate medication to control withdrawal and to address and support cessation efforts.

Most alternative therapies such as laser treatment, acupuncture and hypnosis have not been found to be effective for smoking cessation, although they do not cause harm and may have a positive placebo effect $(1,15,20,26)$.

\section{CONCLUSION}

The promotion of smoking cessation must be a top priority for clinicians and for governments. The Canadian government has contributed to the declining prevalence of smoking by means of high taxation on tobacco products, a greater number of smoke-free environments and advertising bans. However, much remains to be accomplished. The family physician is central to reaching as many smokers as possible and helping them quit. The combination of brief, empathetic and appropriate interventions, support and pharmacological therapies can help encourage smokers to quit and give them their best chance to live smoke-free.

ACKNOWLEDGEMENTS: The authors thank Andrew Pipe of the University of Ottawa Heart Institute, Ottawa, Ontario, for his critical review of the manuscript, and Rosemary Frei and John Cooke of BioScience Communications for their editorial assistance during the manuscript's preparation. The authors also acknowledge funding support from Johnson \& Johnson and McNeil Consumer Healthcare.

CONFLICTS OF INTEREST: Dr Assaad has received honoraria for speaking engagements on motivational interviewing and for smoking cessation from Johnson \& Johnson, GlaxoSmithKline, and Teva Neuroscience. Dr Brosky has received honoraria for speaking engagements and advisory boards and research grants from GlaxoSmithKline, sanofi-aventis and Novartis. Mr Kayser has received honoraria for speaking engagements on motivational interviewing and for smoking cessation from Johnson \& Johnson, Pfizer, GlaxoSmithKline and Teva Neuroscience. Dr Khara has received financial support for research, speaking and the purchase of pharmaceutical products from the following: Genpharm, Johnson \& Johnson, Pfizer and Roche. Dr McIvor has received honoraria for speaking engagements on chronic 
obstructive pulmonary disease and smoking cessation from several pharmaceutical companies including AstraZeneca, Abbott, Bayer, Boehringer Ingelheim, Johnson \& Johnson, GlaxoSmithKline, Nycomed and Pfizer. Dr Weinberg has received honoraria from Johnson \& Johnson and Pfizer for speaking engagements and media campaigns.

\section{REFERENCES}

1. Fiore MC, Jaén CR. A clinical blueprint to accelerate the elimination of tobacco use. JAMA 2008;299:2083-5.

2. US Department of Health and Human Services, Public Health Service. Treating tobacco use and dependence: 2008 update. $<$ http://www.surgeongeneral.gov/tobacco/treating_tobacco_use08. pdf $>$. (Version current at May 15, 2008).

3. Fiore MC, Croyle RT, Curry SJ, et al. Preventing 3 million premature deaths and helping 5 million smokers quit: A national action plan for tobacco cessation. Am J Public Health 2004;94:205-10.

4. Canadian Tobacco Use Monitoring Survey (CTUMS) 2006. Ottawa: Health Canada; 2007. <http://www.hc-sc.gc.ca/hl-vs/tobactabac/research-recherche/stat/ctums-esutc_2006_e.html> (Version current at May 15, 2008).

5. Walker MS, Vidrine DJ, Gritz ER, et al. Smoking relapse during the first year after treatment for early-stage non-small-cell lung cancer. Cancer Epidemiol Biomarkers Prev 2006;15:2370-7.

6. O'Loughlin J, Makni H, Tremblay M, et al. Smoking cessation counseling practices of general practitioners in Montreal. Prev Med 2001;33:627-38.

7. Cunningham JA, Selby PL. Intentions of smokers to use free nicotine replacement therapy. Can Med Assoc J 2008;179:145-6.

8. Tobacco Advisory Group of the Royal College of Physicians. Nicotine addiction in Britain: A report of the Tobacco Advisory Group of the Royal College of Physicians. London (UK): Royal College of Physicians of London, 2000.

9. Mathers CD, Loncar D. Projections of global mortality and burden of disease from 2002 to 2030. PLoS Medicine 2006;3:e442.

10. WHO Report on the Global Tobacco Epidemic, 2008. Geneva: World Health Organization, 2008. < http://www.who.int/tobacco/ mpower/mpower_report_full_2008.pdf > (Version current at May 15, 2008).

11. Kenfield SA, Stampfer MJ, Rosner BA, Colditz GA. Smoking and smoking cessation in relation to mortality in women. JAMA 2008;299:2037-47.

12. Tverdal A, Bjartveit K. Health consequences of reduced daily cigarette consumption. Tob Control 2006;15:472-80.
13. Makomaski Illing EM, Kaiserman MJ. Mortality attributable to tobacco use in Canada and its regions, 1998. Can J Public Health 2004;95:38-44.

14. Baliunas D, Patra J, Rehm J, Popova S, Kaiserman M, Taylor B. Smoking-attributable mortality and expected years of life lost in Canada 2002: Conclusions for prevention and policy. Chronic Dis Can 2007;27:154-62.

15. Raw M, Anderson P, Batra A, et al. WHO Europe evidence based recommendations on the treatment of tobacco dependence. Tob Control 2002;11:44-6.

16. Smoking Cessation Guidelines for Australian General Practice. Practice Handbook 2004 Edition. Australian Government Department of Health and Aging, 2004.

17. American Academy of Family Physicians 'Ask and Act' Program. <http://www.askandact.org> (Version current at May 15, 2008).

18. Butler CC, Rollnick S, Cohen D, Bachman M, Russel I, Stott T. Motivational consulting versus brief advice for smokers in general practice: A randomized trial. Brit J Gen Practice 1999;49:611-6.

19. Soria R, Legido A, Escolano C, López Yeste A, Montoya J. A randomised controlled trial of motivational interviewing for smoking cessation. Brit J Gen Practice 2006;56:768-74.

20. Le Foll B, George TP. Treatment of tobacco dependence: Integrating recent progress into practice. Can Med Assoc J 2007;177:1373-80.

21. Canadian Cancer Society. Smoker's helpline and other quitlines. $<$ http://www.cancer.ca/ccs/internet/ standard/0,3182,3172_49465673_langId-en,00.html> (Version current at May 15, 2008).

22. Canadian Medical Association. Tobacco and Health: <http://www. cma.ca/index.cfm/ci_id/33244/la_id/1.htm> (Version current at May 15, 2008).

23. Eisenberg MJ, Filion KB, Yavin D, et al. Pharmacotherapies for smoking cessation: A meta-analysis of randomized controlled trials. Can Med Assoc J 2008;179:135-44.

24. Nicorette Reduce to Quit. < http://www.reducetoquit.ca/en/> (Version current at May 15, 2008).

25. Longo M, Kalajdzic T, McMorran M. Varenicline (Champix) and serious psychiatric reactions. Canadian Adverse Reaction Newsletter. 2008;18:1-2.

26. White A, Rampes H, Campbell JL. Acupuncture and related interventions for smoking cessation. Cochrane Database Syst Rev 2002;2:CD000009.

27. Doll R, Peto R, Boreham J, Sutherland I. Mortality in relation to smoking: 50 years' observations on male British doctors. BMJ 2004;328:1519.

28. Prochaska JO, Velicer WF, Prochaska JM, Johnson JL. Size, consistency, and stability of stage effects for smoking cessation. Addict Behav 2004;29:207-13. 


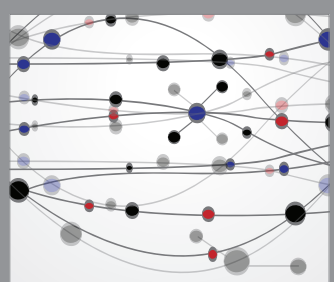

The Scientific World Journal
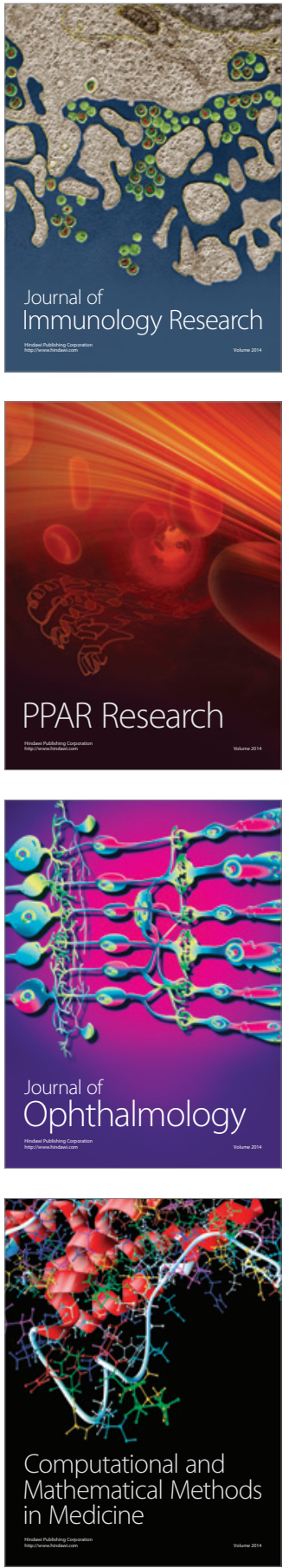

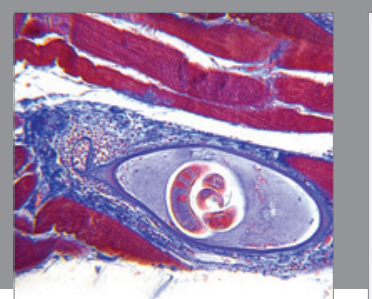

Gastroenterology Research and Practice

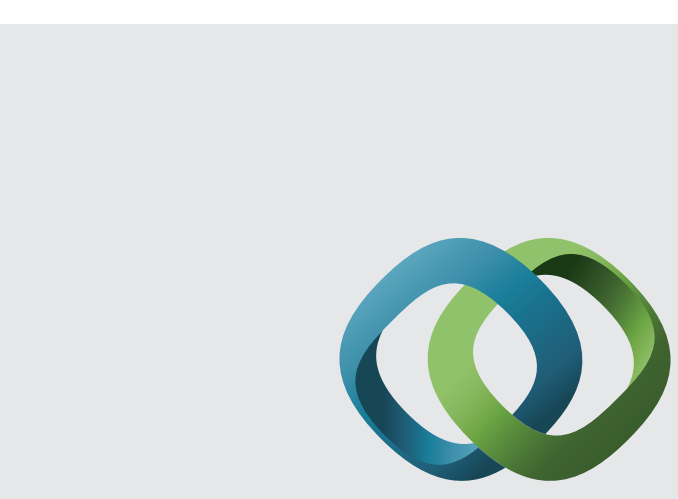

\section{Hindawi}

Submit your manuscripts at

http://www.hindawi.com
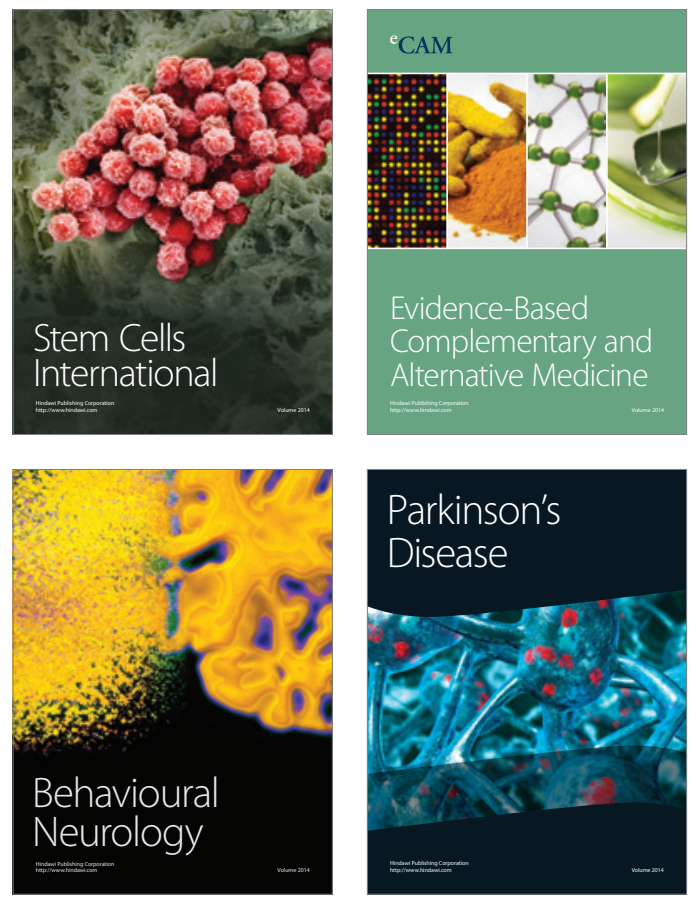
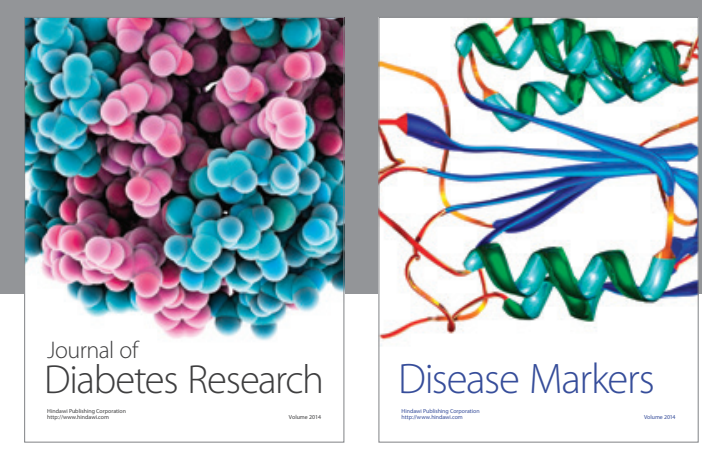

Disease Markers
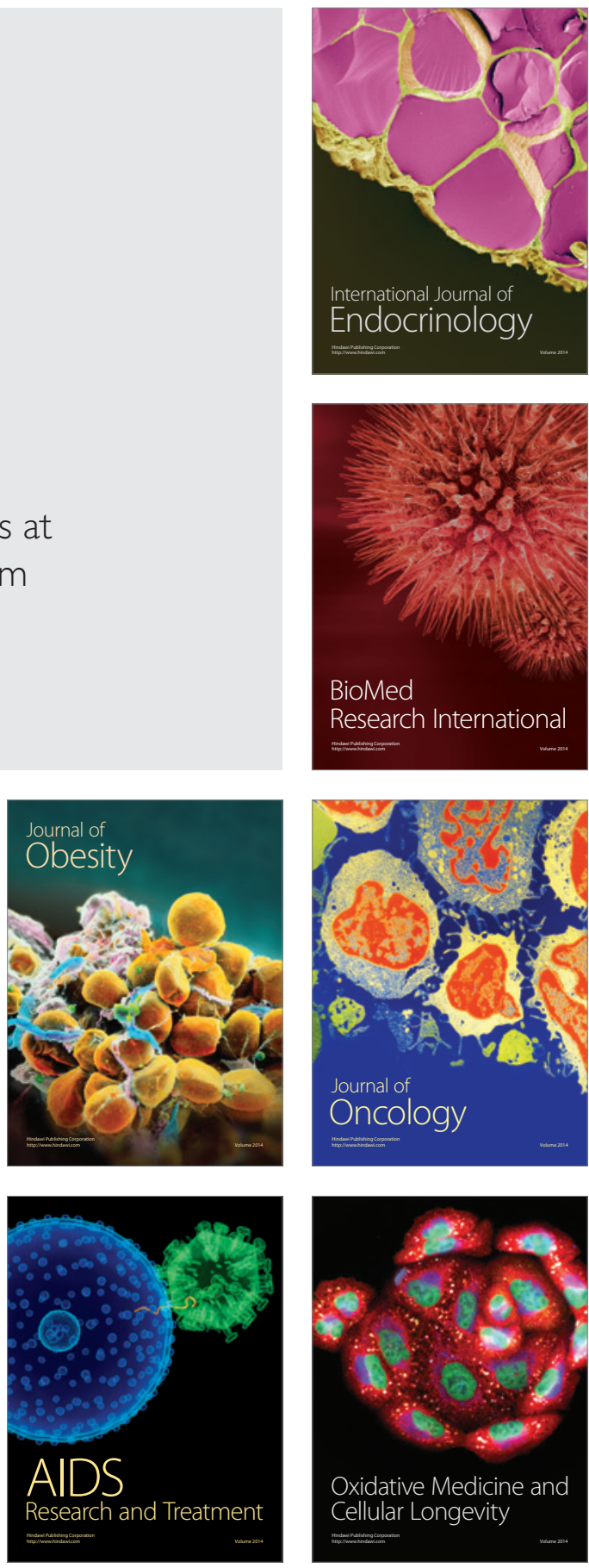